\title{
XXIII. Experiments on the strength of different kinds of woods; made in the Carriage Department, Royal Arsenal, Woolwich
}

\section{Mr. Peter Barlow Jun.}

To cite this article: Mr. Peter Barlow Jun. (1832) XXIII. Experiments on the strength of different kinds of woods; made in the Carriage Department, Royal Arsenal, Woolwich, Philosophical Magazine Series 2, 11:63, 179-183, DOI: $\underline{10.1080 / 14786443208647720}$

To link to this article: http://dx.doi.org/10.1080/14786443208647720

曲 Published online: 25 Jun 2009.

Submit your article to this journal $[\pi$

Џll Article views: 3

Q View related articles $₫$ 
Experiments on the Strength of Woods, by Mr. Barlow, Jun. 179

$$
\begin{aligned}
& \rho \sin p=[0.56697] \sin \left(\mathrm{E}^{\prime}+166^{\circ} 59^{\prime} 24^{\prime \prime}\right)-0.28859 \\
& \rho \cos p=[0.65768] \sin \left(\mathrm{E}^{\prime}+298^{\circ} 18^{\prime} 42^{\prime \prime}\right)+1.39075,
\end{aligned}
$$

and the agreement of the orbit with these observations may

\begin{tabular}{|c|c|c|c|c|c|}
\hline $\begin{array}{l}1779 \cdot 77 \\
1781 \cdot 74 \\
1802 \cdot 34 \\
1804 \cdot 42 \\
1818.0 \\
1818.5 \\
1819 \cdot 0 \\
1819.5 \\
1820 \cdot 0 \\
1820 \cdot 5 \\
1821 \cdot 0 \\
1821 \cdot 5 \\
1822 \cdot 0 \\
182.5 \\
1823.0 \\
1823.5\end{array}$ & $\begin{array}{rr}0 & 0 \\
5 & 56 \\
118 & 39 \\
126 & 14 \\
222 & 33 \\
232 & 41 \\
242 & 30 \\
251 & 34 \\
259 & 39 \\
266 & 42 \\
272 & 45 \\
277 & 56 \\
282 & 24 \\
286 & 15 \\
289 & 36 \\
292 & 33\end{array}$ & $\begin{array}{l}4 \cdot 56 \\
4 \cdot 56 \\
4 \cdot 18 \\
3 \cdot 86 \\
4 \cdot 06 \\
1 \cdot 68 \\
1 \cdot 69 \\
1 \cdot 74 \\
1 \cdot 83 \\
1 \cdot 95 \\
2 \cdot 10 \\
2 \cdot 26 \\
2 \cdot 44 \\
2 \cdot 63 \\
2 \cdot 83 \\
3 \cdot 02 \\
3 \cdot 22\end{array}$ & $\begin{array}{r}1824.0 \\
4.5 \\
1825 \cdot 0 \\
5.5 \\
1826.0 \\
6.5 \\
1827.0 \\
7.5 \\
1828.0 \\
8.5 \\
1829 \cdot 0 \\
9.5 \\
1830.0 \\
0.5 \\
1831.0\end{array}$ & $\begin{array}{lr} & \circ \\
295 & 9 \\
297 & 29 \\
299 & 34 \\
301 & 28 \\
303 & 12 \\
304 & 47 \\
306 & 15 \\
307 & 37 \\
308 & 54 \\
310 & 6 \\
311 & 14 \\
312 & 18 \\
313 & 19 \\
314 & 17 \\
315 & 13\end{array}$ & $\begin{array}{l}3 \cdot 42 \\
3 \cdot 61 \\
3 \cdot 80 \\
3 \cdot 98 \\
4 \cdot 16 \\
4 \cdot 33 \\
4 \cdot 50 \\
4 \cdot 66 \\
4 \cdot 82 \\
4 \cdot 97 \\
5 \cdot 11 \\
5 \cdot 24 \\
5 \cdot 37 \\
5 \cdot 50 \\
5 \cdot 61\end{array}$ \\
\hline
\end{tabular}
be seen from the following ephemeris :

The following Table exhibits its comparison with Struve's

\begin{tabular}{|c|c|c|c|c|}
\hline \multirow{6}{*}{$\begin{array}{l}1825 \cdot 55 \\
1826 \cdot 8 \\
1827 \cdot 4 \\
1828 \cdot 75 \\
1829 \cdot 4\end{array}$} & \multicolumn{2}{|c|}{ Calculated. } & \multicolumn{2}{|c|}{ Differences. } \\
\hline & $30 i^{\circ} 39$ & $4: 00$ & $\begin{array}{l}1 \\
0\end{array}$ & $0^{\prime \prime} \cdot 00$ \\
\hline & 30541 & 4.43 & +125 & +0.09 \\
\hline & 30721 & $4 \cdot 63$ & +75 & $+0 \cdot 12$ \\
\hline & 31041 & $5 \cdot 04$ & +53 & +0.25 \\
\hline & 3125 & $5 \cdot 21$ & +32 & +0.03 \\
\hline
\end{tabular}
observations :

The total discrepancy between the orbit and the observations of the years 1818-1823, proves that if this system obeys the law which we have assumed, the great diminution of the distance of 1825 , in comparison with that of 1830 , cannot have taken place.

[To be continued.]

XXIII. Experiments on the Strength of different Kinds of Woods; made in the Carriage Department, Royal Arsenal, Woolwich. By Mr. Peter Barlow, Jun. As. Inst. Civ. Eng.*

THE following series of experiments, several of which I attended, being made on species of woods, the strength of which has not been previously ascertained, will I trust not

- Communicated by the Author. 
be considered uninteresting to the readers of the Phil. Mag. and Annals; particularly as the results are not only curious, but may probably lead to useful and important investigations, as connected with the introduction into and the growth of foreign timber in this country, as well as to important improvements in the presentsystem of planting. Under this impression I have been induced to send them to you as an addition to the several others on the same subject which have appeared at different times in this Journal.

The experiments originated in an investigation of the comparative properties of acacia and oak by W. Withers, Esq. of Norfolk, whose object appears to have been to encourage the planting of the former in many situations instead of the latter, as a wood of great durability, and of quicker growth. In order to have a comparison made of their relative strengths, he forwarded specimens of both woods to Woolwich, and the results of the experiments will be seen in the following Table.

Another question arose with Mr. Withers relative to the strength of oak, the growth of which had been encouraged by culture, compared with oak of the ordinary slow growth*. The specimens connected with the latter subject, the author informs us, were received from Mr. W. Boorne of Erpingham; the one from a fast and the other from a slow growing tree. They are marked Nos. 3 and 4 in the Table of Experiments. The former was grown on a very good strong soil, its age was supposed about 60 years, and it contained from 38 to 40 cubic feet of timber: the other, No. 4, was about 120 years old, and was grown upon light soil, with gravel about 2 feet below the surface. This tree contained about 80 cubic feet, but Mr. Boorne considers that if No. 3 had stood to attain the same age, it would have made at least 40 feet more than that tree. The other two specimens were from trees furnished by Mr. Samuel Farrow of Diss, Norfolk, grown on the same piece of land : that from which No. 5 was cut, stood near the rack-yard of the farm by the side of a ditch, into which ran a great deal of moisture from the yard; and he has no doubt that, independently of the nourishment obtained by it from the ditch, very many of the smaller roots reached as far as the rack-yard; and the tree grew rapidly, and contained when cut down 120 feet of timber. The tree from which No. 6 was cut, grew, as before stated, in the same field, but had none of the advantages above spoken of; but still the soil was good, with a lightish blue clay bottom. The tree grew well, but not in any degree so fast as the other: it contained about 90 feet of

- See a Letter to Sir Henry Stewart, Bart. on the improvement in the quality of timber, by W. Withers, Esq.

timber, 
timber, and it is the opinion of persons on the spot that they were both planted together.

Thus far the experiments were made with a particular object; but as there were in store, in the Royal Arsenal, many woods, not in very common use, but which are grown abundantly in some countries, and from the appearance of which great strength was anticipated, Mr. Bossey, foreman in the carriage department, was requested to prepare specimens, which were submitted to the same test as the former ones.

These results are interesting, some of the woods being more than double the average strength of oak : several of these specimens were sent from Berbice by Capt. Gipps of the Royal Engineers, who speaks very highly of their durability.

The apparatus made use of in the experiments consisted simply of two upright posts, fixed securely at one end in the ground, and at the other to the tie beam of the roof of a shed; on each of these were firmly attached two pieces of hard wood formed to an edge, on which the specimens to be experimented upon were placed, and a scale suspended from the centre to receive weights. To ascertain the relative stiffness or elasticity, the weight which caused a deflection of one inch, was registered, which was denoted by a rod attached to the tie beam so as to point downwards in front of the middle of the specimen, and one inch below the upper surface; so that when one inch of deflection had taken place, it was shown by the rod just passing clear of the piece under experiment.

In the Table, the Ist column contains the names of the woods; the 2nd the specific gravity; the 3rd the weight which caused 1 inch deflection, or $\frac{1}{5}$ th part of the length; the 4 th, the breaking weight; the 5 th, the relative elasticity from the formula $\mathrm{E}=\frac{l^{3} w}{a d^{3} \delta}$; the 6 th, the strength from the formula $\mathbf{S}=\frac{l w}{4 a d^{2}} ;$ where $l$ is the length, $a$ the breadth, $d$ the depth, $\delta$ the deflection in inches, and $w$ the weight in pounds; by which they become comparative with the various experiments in Barlow's Essay on the Strength of Timber; and the last column contains any requisite description or remarks.

The pieces were each accurately cut and planed 2 inches square, and 5 feet in length; and the distance of the props on which they were broken was exactly 50 inches: they were selected with great care by Mr. Bossey, who assisted at the experiments, and registered and delivered the following results. 
182 Experiments on the Strength of Woods, by Mr. Barlow, Jun.

Table of the Strength and Elasticity of various Woods of English and Foreign Growth.

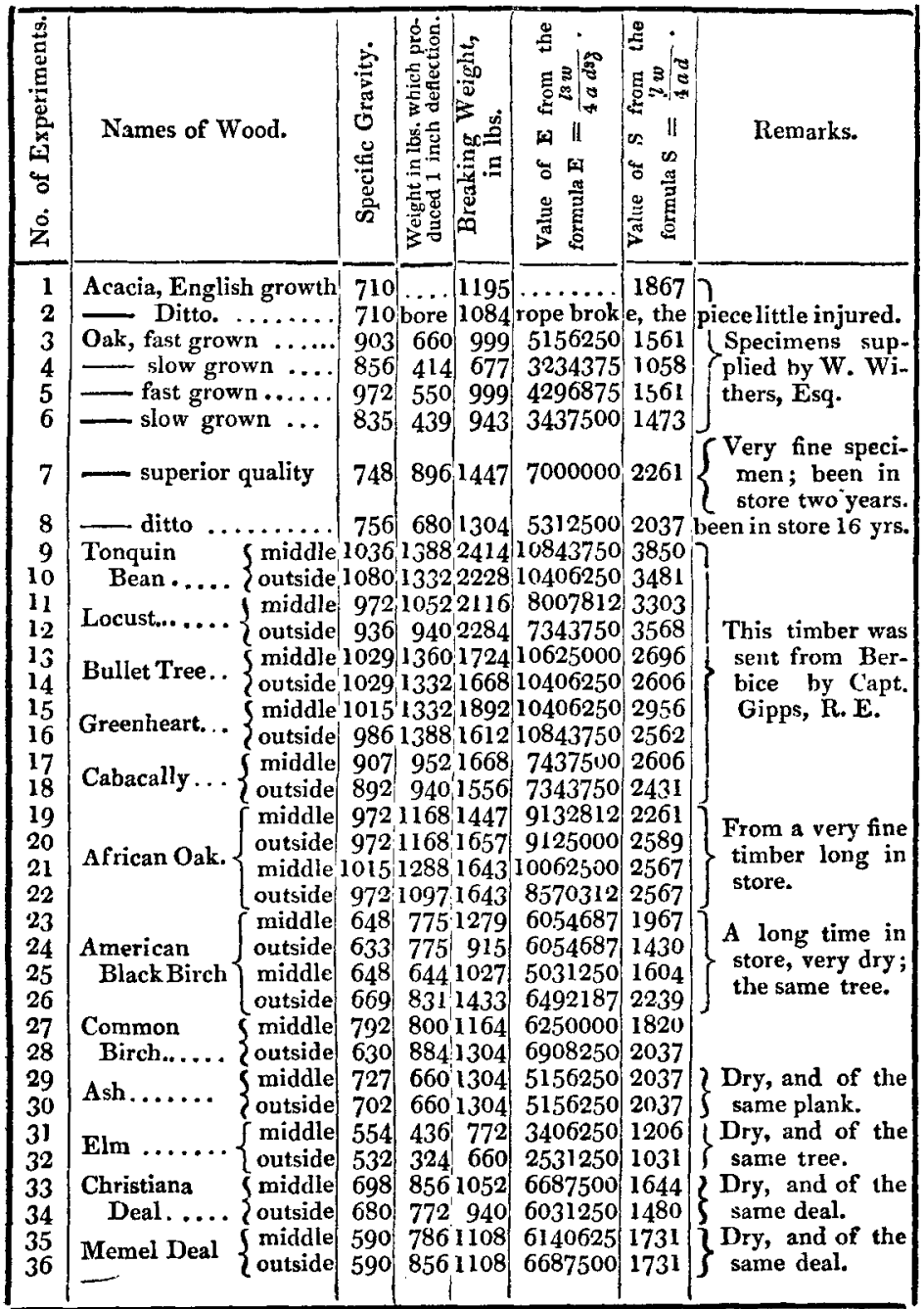

It is to be regretted that the results of the acacia were not more particularly noted; but not having in view at that time to carry on so extensive a course of experiments, means were not taken to ascertain its stiffness. The second specimen, after the rope broke, was found but little injured by the experiment, which certainly indicates considerable power of elasti- 
city, although the exact amount was not numerically ascertained. This specimen was preserved unbroken. Upon the whole, however, it has the advantage of the oaks in strength, except those marked No. 7 and 8 , which were remarkably fine specimens; but it will be found by referring to Barlow's Essay to greatly exceed the strength of oak in general.

The results of the oak experiments seem certainly to be in favour of the fast grown. "These experiments," Mr. Withers observes, " throw new light upon the subject, and lead to the most important conclusions. They prove not only that fast growing timber is superior in quality to that of slower growth, but that by the constant application of manure to the roots of trees planted even in good soil, nearly double the quantity of timber may be obtained in the same period, while its strength instead of being diminished will be thereby increased."

XXIV. Papers relating to a Design for the Ner London Bridge, on the Principle of Cementitious Architecture:-exhibited to the Committee of the House of Commons, on the 11 th of April 1823. By JoHN WhITE, Esq.*

$$
\text { [With a Plate.] }
$$

Contents.-Mr. White's Letter to the Comptroller of the Estates of London Bridge.-Mr. Newman to Mr. White.-Mr. White to Dr. Gregory. - General Observations on the Designs for London Bridge.-Dr. Gregory's Reply.-Dr. Gregory's Observations.-Mr. White to the Editor of the Quarterly Journal.-Account of Experiments on Cements.-Inference from these Experiments.-Extract from the Memoirs of Savary, Duke of Rovigo.

\section{To the Comptroller of the Estates of London Bridge. Sir,-}

I BEG leave to submit to your notice the following suggestions upon the subject of the removal of London Bridge, to which the mind of the public is at the present time so much directed, premising that I agree with the Second Report of the Committee of the House of Commons, that a work of such public importance as the plan of 1814 should not be undertaken without the greatest and most unequivocal certainty of ultimate success, and that it is, as the Committee conceived, extremely doubtful whether a New Bridge would not ultimately be found less expensive than the proposed alteration.

The River Thames is considered as a river having an artificial obstacle, producing a rapid and extremely irregular fall

* Communicated by the Author.-Mr. Telford's Report, in 1823, on the effects on the Thames of rebuilding London Bridge, and another paper on the same subject, will be found in Phil. Mag. vol. Ixii. p. 21, 28 . 